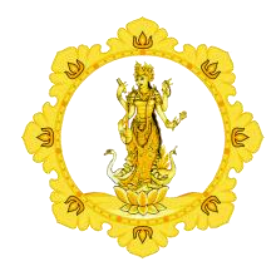

KALANGWAN

JURNAL PENDIDIKAN AGAMA, BAHASA DAN SASTRA

Vol. 11 No. 1 Maret 2021

\begin{tabular}{|l|l|l|}
\hline p-ISSN : 1979-634X & e-ISSN : 2686-0252 & http://ejournal.ihdn.ac.id/index.php/Kalangwan
\end{tabular}

\title{
"BABAR LONTAR" STRATEGI GELIAT BUDAYA PELESTARIAN LONTAR DI BALI PADA MASA PENDEMI COVID-19
}

\author{
Oleh : \\ Putu Dedi Handana \\ Penyuluh Bahasa Bali Kabupaten Bangli \\ E-mail: putusongan18@gmail.com
}

Diterima 03 Januari 2021, direvisi 05 Januari 2021, diterbitkan 31 Maret 2021

\begin{abstract}
The importance of knowing, studying, and disseminating the existence of lontar as a strategy to preserve ancestral heritage so that it can be a reference source for information related to previous human civilizations from various aspects of life, such as cultural, social, agricultural, medical, and so on, is very important. Efforts have been made to physically maintain the presence of lontar so that it is not easily damaged and can still be read as a source of cultural heritage. In the midst of the Covid-19 pandemic, all activities are starting to be limited, but active to disseminate the existence of lontar manuscripts is no longer a taboo thing but as something that must be known so that the perception of "tenget" can be changed to draw noble values from a lontar script. This activity can be carried out by exposing through vigorous "babar lontar" this activity is carried out through virtual activities so that conservation efforts are still ongoing in the midst of a pandemic.
\end{abstract}

Keywords: Preserve, Babar Lontar

\section{PENDAHULUAN}

\subsection{Latar Belakang Masalah}

Bali yang merupakan salah satu provinsi yang ada di Indonesia memiliki aneka keragaman dan keindahan dari aspek geografis, budaya, ekonomi, sosial yang menjadi daya Tarik tersendiri bagi masyarakat Bali. Keragaman budaya yang dimiliki bali menjadi salah satu roh dari identitas yang dimiliki Bali yang tetap dijaga eksistensinya. Dalam bukunya Gde Aryanta Soethama yang berjudul Bali Tikam Bali menuliskan bahwa masyarakat Bali sejak dulu dikenal senang berkumpul, dan dimaknai bahwa mereka baru mempunyai makna ketika mereka bersama. Hampir seluruh romantika 
hidup mereka adalah dinamika kelompok. Kebudayaan dan kesenian yang mereka hasilkan, tak pernah mengagungkan sosok individu. Kesenian menjadi milik bersama, diciptakan dan dimotori oleh seseorang, namun kemudian menjadi hak barengbareng(Gde Aryantha Soethama, 2014:74). Keunikan-keunikan yang ada di Bali tentunya diikat oleh suatu keragaman yang menjadi benteng budaya salah satunya bidang Bahasa, aksara dan sastra bali.

Keberadaan Bahasa, aksara dan sastra bali sebagai media komunikasi oleh masyarakat bali dilakukan dengan berbagai metode. Salah satunya dengan metode menyurat dalam suatu sarana yang di bali disebut lontar. Seiring perkembangan arus golbalisasi dan teknologi, tidak saja hanya menggeser berbagai kearifan-kearifan lokal yang telah tumbuh seiring dengan perkembangan masyarakat itu sendiri tetapi juga menggeser aspek literasi yang ada dalam masyarakat bali. Di tengah berkembangnya teknologi grafika dan media digital telah memunculkan fenomena lontar di bali sudah semakin terpingirkan terlebih lontar diidentikan dengan sesuatu yang tenget (sakral) menjadikan generasi muda merasa asing dengan keberadaan lontar, bahkan banyak masyarakat bali yang tidak mengenal lontar. Lontar merupakan bagian dari budaya masyarakat Bali memuat nilai-nilai luhur peradaban masyarakat bali berupa ajaranajaran yang sarat dengan tuntutan kehidupan. Keberadaan lontar di bali banyak tersebar di berbagai desa adat, koleksi pribadi, perpustakaan, maupun lontar yang disakralkan misalnya lontar-lontar yang disimpan di pura atau tempat suci kemudian lontar yang disucikan.

Eksistensi keberadaan lontar di bali sebagai bagian dari budaya memiliki nilai tersendiri sebagai salah satu rangkaian daya Tarik wisata bagi pulau Bali terlebih lontar tidak hanya saja dikenal oleh masyarakat Bali tetapi sudah dikenal dalam masyarakat dunia mengenai lontar dengan anggapan bahwa lontar identik dengan hal magis- relegius, seperti yang ditulis oleh A.A. Gde Alit Geriai bahwa dari perspektif budaya dan masyarakat Bali sastra dipandang sebagai suatu yang memuat hal-hal yang suci, arkais, dan sakral relegius. Dengan kata lain, seorang yang akan menggeluti dunia lontar, dituntut memiliki pengetahuan moral-spiritual dan relegius yang memadai serta harus disucikan (diinisiasi) secara lahir batin (A.A.Gde Alit Geriai, 2010:35) hal ini menjadikan pengetahuan dan minat membaca lontar semakin tidak diminati terlebih di era revolusi industry saat ini yang identik dengan flatform teknologi informasi. Berbagai macam upaya telah dilakukan oleh pemerintah maupun pemerhati lontar untuk mempertahankan keberadaan lontar misalnya dengan melakukan giat konservasi lontar, digitalisasi dan penterjemahan lontar yang dilakukan secara langsung. Pandemi Covid saat ini yang melanda seluruh dunia mengakibatkan ruang gerak yang semakin terbatas dalam berbagai aspek kehidupan.

Salah satu persoalan dalam upaya pelestarian keberadaan lontar di masa pandemik diakibatkan oleh terbatasnya akses untuk melakukan giat-giat yang sebelumnya dilakukan secara langsung untuk mengidentifikasi keberadaan-keberadaan lontar di bali yang selanjutnya dilakukan giat pelestarian saat ini tidak bisa dilakukan, sehingga diperlukan upaya baru untuk meningkatkan minat koleksi, membaca, memahami keberadaan dari suatu lontar yang memuat bahsa, aksara, dan sastra.

\section{PEMBAHASAN}

\subsection{Payung Hukum Perlindungan}

\section{Bahasa, Sastra, dan Aksara di Bali}

Mengamati persoalan kian tergerusnya peradaban budaya bali yang bersumber dari lontar mengetuk hati untuk melakukan reframing terhadap keberadaan lontar itu sendiri. Seperti kita ketahui melalui cerita tetua bahwa lontar memiliki nilai luhur yang memuat sebagian cara hidup, etika, sopan santun, bagaimana menjalin hubungan dengan semesta ini. Koenjaraningrat mengungkapkan terdapat tujuh system yang berhubungan dengan budaya, yaitu system Bahasa, system pengetahuan, system 
organisasi sosial, system mata pencaharian, system kesenian, system religi, dan system peralatan dan teknologi (Koenjaraningrat : 2002). Bahasa sebagai salah satu komponen penting dalam peradaban kehidupan manusia harus tetap lestari. Bahasa memiliki fungsi yang teramat penting untuk menghubungkan, menyampaikan, mentrasmisikan, berbagai macam bentuk informasi yang menunjang kehidupan manusia atau lingkungan tersendiri. Berbagai negara memiliki bahasanya masing-masing yang digunakan sebagai alat komunikasi antar warganya baik itu Bahasa resmi, maupun Bahasa daerah. Indonesia salah satunya memiliki ragam Bahasa daerah yang dikarenakan banyak suku yang beragam di Indonesia salah satunya Bali.

Mengenali peradaban Bali purba di dalam perjalanan peradaban evolusi manusia dari jaman ke jaman, yang juga merupakan cikal bakal kehidupan manusia bali dalam percampuran kehidupan, dari ribuan bahkan puluhan ribu tahun yang silam. Apalagi jika dilihat dari catatan evolusi alam, yang begitu banyak mengalami perubahan struktur atau bentuk yang juga disebabkan oleh banyak bencana yang juga terjadi, seperti letusan gunung batur sampai 26 bahkan 28 ribu kali letusan, kejadian yang sudah berlalu tersebut sesuai dengan catatan Badan Penanggulangan Nasional ke Gunung Apian atau Vulcanologi ( $\mathrm{BPNVG}$ ).

Jika menelusuri perkembangan peradaban manusia bali tempo dulu (purba) tidak banyak ditemukan informasi yang dapat ditelusuri karena memang manusia bali di jaman tersebut belum mengenal logam sebagai suatu peralatan yang dibandingkan dengan jaman Neolithicum atau jaman batu baru, jauh lebih banyak yang dapat dibuktikan sebagai pembuktian peninggalan sejarah. Sejarah perkembangan manusia telah membawa perubahan peradaban manusia itu sendiri sesuai dengan perkembangan jamannya.

Perkembangan peradaban manusia diiringi dengan perkembangan cara penyampaian informasi dalam berkomunikasi. Sejak jaman pra-sejarah cara manusia berkomunikasi dengan menggunakan berbagai ragam Bahasa terus berkembang sampai saat ini. Pada masa prasejarah manusia berkomunikasi terbatas pada pengenalan melalui wujud atau bentuk yang mereka temukan. Manusia menggambarkan informasi atau menyampaikan informasi yang mereka peroleh dengan cara menorehkan bentuk buruannya di dinding gua misalnya, karena manusia di jaman tersebut memiliki kemampuan yang terbatas misalnya menyampaikan informasi hanya melalui suara dengusan, Bahasa isyarat, dan gerakan tubuh sebagai bentuk komunikasi.

Peradaban manusia di zaman perunggu sudah mulai menunjukan kemajuan bahwa manusia dizaman tersebut sudah mulai melakukan komunikasi dengan mengunakan tulisan-tulisan yang menjadi media komunikasi manusia. Khususnya di Bali tulisan yang dikenal tersebut disurat kedalam suatu media daun yang bahan dasar pembuatannya, yaitu rontal atau daun ental yang yang selanjutnya disebut dengan lontar, pada umumnya dianggap sebagai media informasi manusia di jaman tersebut karena peradaban zaman tidak semodern hari ini.

Keberadaan lontar di bali memuat setidaknya sudut pemikiran dari perkembangan peradaban manusia di bali pada khususnya mengenai berbagai aspek kehidupan misalnya, aspek cara bertahan hidup, budaya, pola hubungan, sistem ekonomi, dan informasi lainnya. Memahami isi sebuah lontar akan memberikan gambaran dan komparasi terhadap dinamika kehidupan yang berpengaruh terhadap perilaku sosial dari manusia itu sendiri. Substasi lontar ditulis dalam bentuk aksara Bali yang berbeda secara bentuk dengan tulisan modern.

Lontar di bali pada zaman dahulu juga dipandang memuat berbagai macam kesustraan tentang ilmu pengetahuan, wariga, usadha/pengobatan tradisional, mantra/puja, ilmu kawisesan, babad/perjalanan leluhur, upacara/upakara.

Begitu pentingnya muatan lontar sehingga keberadaan lontar patut untuk dilestarikan karena keberadaan lontar salah satunya akan menjadi jembatan yang menghubungkan peradaban masa lalu, 
sekarang dan masa depan nantinya, hal ini dikarenakan informasi yang dihimpun akan berbeda di setiap jaman atau peradaban manusia itu sendiri.

Lontar yang ada di bali sudah menjadi warisan budaya bagi masyarakat bali saat ini, melalui pengetahuan yang diperoleh dari isi lontar pembaca akan mengetahui bukti identitas diri dari masyarakat itu sendiri, jika hal ini hilang maka kita akan kehilangan jati diri kita sebagai masyarakat bali yang seperti apa, selain itu pengetahuan terhadap isi lontar dapat memberikan kita pemahaman terhadap hubungan manusia dengan leluhurnya di masa lalu, sebagai wujud bakti atas perjuangan kehidupan leluhur-leluhur manusia itu sendiri dalam bertahan hidup. Huruf yang digunakan dalam tulisan lontar-lontar di bali cenderung menggunakan aksara bali dalam Bahasa bali, kemudian ada juga dalam bentuk teks-teks sastra kuno yang disusun dalam Bahasa jawa kuno kawi dan sansekerta.

Semakin rendahnya masyarakat bali pada khususnya dalam berkomunikasi menggunakan Bahasa bali dan menulis dengan aksara bali menjadi faktor utama semakin menurunnya minat atau keinginan untuk membuka catatan-catatan peradaban manusia di masa lalu yang tersurat dalam teks-teks lontar di Bali, sehingga diperlukan suatu upaya untuk menguatkan kembali keberadaan warisan budaya bali melalui penguatan bidang Bahasa, sastra, dan aksara bali sebagai modal untuk memahami teks-teks suatu lontar, sehingga dengan pemahaman terhadap Bahasa, sastra dan aksara bali dapat menambah minat untuk membaca, mengupas, menterjemahkan isi dari teks-teks lontar yang ada di Bali sehingga tetap bisa lestari sebagai warisan budaya. Mengutip pendapat dari I Ketut Artadi dalam bukunya berjudul Kebudayaan Spiritualitas mengungkapkan bahwa kebudayaan tidak dapat dipertahankan, tetapi harus dilestarikan. Kebudayaan selalu berubah mengikuti zaman dan perubahan itu tidak dapat dihentikan. Perubahan kebudayaan adalah pertanda perubahan zaman dan intelektualitas manusia, sehingga nenek moyang kita yang sangat terbelakang pikirannya tidak hendak mempertahankan kebudayaannya. Jika nenek moyang kita mempertahankan kebudayaannya mungkin kita masih di zaman batu ( I Ketut Artadi, 2011:79)

Perubahan kebudayaan, berarti perubahan pilihan nilai-nilai atau berubahnya penilaian terhadap nilai-nilai oleh manusia. Sehingga nilai-nilai lama ditinggalkan dan nilai-nilai baru mulai dijunjung tinggi. Penghargaan terhadap nilai-nilai baru dan ditinggalkannya nilai lama, akan menyebabkan adanya benda-benda budaya lama, sastra-sastra lama yang pada zamannya dijunjung tinggi, tetapi saat zaman sudah berubah kebudayaan lama itu akhirnya menjadi benda-benda sejarah. Bangsa-bangsa menjadi semakin maju dan kebudayaanya menjadi semakin bermartabat jika banagsa itu belajar dari sejarahnya ( I Ketut Artadi, 2011:79)hal ini relevan dengan betapa pentingnya melestarikan identitas diri suatu budaya yang telah diwarisi sebagai suatu peradaban manusia itu sendiri.

Ketut Wiana dalam bukunya berjudul mengapa Bali disebut Bali? Mengungkapkan Bali yang kecil secara fisik namun akan dapat memberikan kontribusi yang cukup berarti pada kehidupan umat manusia di Bali khususnya dan di tingkat nasional bahkan di tingkat internasional pada umumnya. Kontribusi tersebut akan dapat diberikan oleh Bali apabila kita dapat mengetahui letak kekuatan Bali itu sendiri. Letak kekuatan Bali itu adalah pada komposisi kekuatan alam dan kekuatan kebudayaanya ( Ketut Wiana, 2004: 20) kebudayaan Bali sebagai suatu kekuatan bali sudah sewajarnya tetap dilestarikan dengan berbagai upaya salah satunya penguatan melalui instrument hukum.

Bahasa, sastra, dan aksara Bali penting untuk mendapat perlindungan secara hukum sebagai langkah penguatan atau maupun melindungi keberadaan Bahasa, sastra, dan aksara sebagai salah satu identitas budaya bali sebelum ditemukannya huruf latin, masyarakat bali berkomunikasi dengan menggunakan aksara bali dari jaman dulu yang dimuat dalam naskah-naskah lontar, prasasti, purana, dan berbagai manuskrip lainnya yang memuat keseluruhan 
pengetahuan, tradisi, seni, budaya, serta kearifan lokal dari leluhur. Sehingga untuk memuliakan budaya Bahasa, sastra, dan aksara Bali Pemerintah Provinsi Bali mengeluarkan suatu produk hukum berupa Peraturan Gubernur Bali Nomor 80 Tahun 2018 tentang Perlindungan dan Penggunaan Bahasa, Sastra, dan Aksara Bali serta penyelenggaraan Bulan Bahasa Bali. Pergub ini juga menjadi acuan dalam penentuan posisi aksara bali dalam penulisan papan nama kantor, jalan, gedung, sarana pariwisata, fasilitas umum lainnya di atas nama yang ditulis nama yang ditulis dengan huruf latin. Penggunaan aksara bali sebagai langkah strategis untuk penguatan identitas budaya daerah sebagai bagian dalam kerangka kebudayan nasional.

Melalui instrument hukum tersebut pelestarian Bahasa, sastra, dan aksara Bali dapat dilakukan secara berkesinambungan sehingga masyarakat Bali tetap mampu melestarikan khasanah warisan budaya yang ada di Bali dengan pengetahuan berbahasa dan menulis aksara Bali masyarakat bali diharapkan mampu menumbuhkan minat untuk mengetahui perdaban manusia bali melalui pembacaan naskah-naskah yang di surat dalam lontar-lontar di Bali.

\subsection{Babar Lontar sebagai Strategi Pelestarian Lontar Di Bali di Masa Pandemi Covid-19}

Upaya pelestarian lontar dewasa ini dilakukan dalam bentuk perawatan dan penyelamatan manuskrip lontar yang dilakukan oleh masyarakat yang masih memiliki lontar yang dilakukan dengan berbagai cara hal ini mengingat bahwa masyarakat Bali menganggap manuskrip lontar sebagai sesuatu yang "tenget"'(sakral) sehingga pada saat manuskrip lontar tersebut dirawat terlebih dahulu akan diawali dengan prosesi atau ritual memohon ijin dalam bentuk menghaturkan sesajen kemudian baru dilanjutkan dengan aktivitas perawatan lontar dengan cara yang kovensional untuk menjaga keutuhan dari lontar tersebut dalam bentuk preservasi manuskrip lontar.
Merujuk dari hasil penelitian I Nyoman Sedana,dkk mengungkapkan bahwa manuskrip lontar merujuk kepada istilah manuskrip yang berasal dari Bahasa latin yaitu manuscript yang berarti "manu srciptus" di tulis tangan yang secara khusus, atau yang dapat pula dikatakan sebuah dokumen tertulis yang ditulis tangan. Suatu naskah kuno Bali yang disebut lontar merupakan suatu karya tulis dengan tangan, dengan bidang tulis yang memanjang biasanya berukuran $3 \times 40 \mathrm{~cm}$ dan ditulis dari kiri ke kanan, adapun alat tulis yang dipergunakan dalam menulis adalah :

1) Pangrupak atau pangutik atau pisau berujung runcing,

2) Pangirikan atau pelobang

3) Pelagbang atau alat pemasung

4) Tepesan. ( I Nyoman Sedana, dkk, 2013: 94)

Sebelumnya telah dituliskan bahwa kepercayaan masyarakat bali terhadap keberadaan lontar dipandang sebagai suatu yang memiliki nilai magis religious sehingga memang cenderung disakralkan. Pada umumnya kebanyakan manusript lontar memuat nilai-nilai luhur tentang tata cara berperilaku dalam hidup yang ditulis dengan menggunakan aksara Bali serta sebagai naskah lampau yang seharusnya tetap terjaga sebagai suatu sumber peradaban kehidupan kini terancam mengalami kerusakankerusakan terutama terhadap lontar-lontar yang dimiliki secara pribadi oleh masyarakat karena minimnya tata cara perawatan terhadap lontar tersebut yang menyebabkan banyak sekali lontar-lontar yang sudah rusak dan tidak dapat dibaca . Sehingga sangat penting diupayakan strategi-strategi sebagai langkah pelestarian keberadaan lontar di Bali pada khususnya agar dapat diwarisi dan dipelajari sebagai suatu sumber. Aktivitas pelestarian sebagai langkah preventif telah dilakukan melalui berbagai strategi yang dilakukan oleh pemerintah, mahasiswa, peneliti, pemerhati bidang lontar( Bahasa, sastra, dan aksara bali), maupun masyarakat dilakukan melalui konservasi lontar yang merupakan suatu giat untuk melakukan 
perawatan, pemeliharaan, dan penyelamatan naskah lontar agar tidak mudah rusak.

Sebagai sebuah strategi, konservasi lontar bertujuan merawat, memelihara dan menyelamatkan keberadaan lontar sebagai warisan leluhur yang memiliki nilai peradaban yang tinggi dalam kehidupan manusia. Kegiatan ini dilakukan secara berkesinambungan akan tetapi ditengah pandemic covid-19 aktivitas konservasi lontar secara tidak langsung telah terbatas karena akses untuk melakukan perawatan dari pemilik lontar cukup terbatas. Aktivitas yang banyak dilakukan melalui kegiatan virtual juga berdampak terhadap upaya pelestarian keberadaan lontar di Bali, sehingga suatu strategi lain juga harus dilakukan agar kegiatan pelestarian lontar tersebut tidak tertunda. "Babar Lontar" sebagai salah satu strategi yang digunakan untuk pelestarian keberadaan lontar di Bali, babar lontar memiliki makna kegiatan untuk membentangkan, mengembangkan ataupun meluaskan betapa.

Pentingnya keberadaan lontar sehingga penting untuk dilestarikan. Di era pandemi kegiatan babar lontar ini menjadi salah satu alternatif atau strategi pelestarian lontar agar keberadaan lontar semakin dikenal dan tidak terasing dalam khasanah kebudayaan bali pada khususnya.

\section{PENUTUP}

Khasanah kebudayaan Bali dapat dilihat dari berbagai fitur salah satunya yang menjadi ciri khas yakni dari aspek Bahasa, sastra, dan aksara yang dipergunakan sebagai sarana komunikasi oleh masyarakat Bali. Dimulai sejak dikenalnya suatu tulisan, kehidupan manusia terdahulu telah mencatatkan atau menyurat segala aspek penting dalam kehidupan terdahulu dalam suatu media yang dikenal sebagai naskah lontar yang memuat berbagai macam nilainilai luhur peradaban kehidupan manusia sebelumnya yang di tulis dengan aksara.
Seiring dengan kemajuan zaman keberadaan lontar semakin tenggelam yang hanya disimpan sebagai sesuatu yang dianggap memiliki nilai magis relegius sehingga sangat minim sekali masyarakat yang mau mempelajari naskah lontar sebagai suatu sumber pengetahuan. Sebagai suatu warisan budaya yang harus dipertahankan berbagai bentuk upaya pelestarian telah dilakukan salah satunya melalui konservasi lontar yang bertujuan untuk menjaga keberadaan lontar dengan cara dirawat, dan dipelihara dengan standar perawatan naskah lontar dengan harapan kedepannya dapat diwariskan kepada generasi-generasi berikutnya sebagai pedoman dalam menjalani kehidupan. Selain itu di era pandemic strategi pelestarian dapat dilakukan melalui kegiatan babar lontar yang dilakukan oleh pegiat-pegiat bahsa, sastra, dan aksara di Bali yang dilakukan secara virtual. Harapannya melalui kegiatan ini masyarakat luas lebih memahami arti penting untuk menjaga dan mengetahui substansi yang dimuat dalam naskah lontar.

\section{DAFTAR PUSTAKA}

I Ketut Wiana. 2004. Mengapa Bali disebut Bali. Paramita. Surabaya

I Ketut Artadi. 2011. Kebudayaan Spiritualitas Nilai Makna dan Martabat Kebudayaan. Pustaka Bali Post. Denpasar

Koenjaraningrat. 2002. Kebudayaan Mentalitas dan Pembangunan. PT Gramedia Pustaka Utama. Jakarta

I Nyoman Sedana. Ninis Agustini Damayanti. Ute Lies Siti Khadijah. 2013. Preseevasi Berbasis Kearifan Lokal ( Studi Kasus Mengenai Preservasi Preventif dan Kuratif Manuskrip Lontar sebagai Warisan Budaya di Kabupaten Klungkung Bali). Jurnal Kajian Informasi dan Perpustakaan. Volume 1 Nomor 1 Juni 2013. Available from : URL: file:///C:/Users/HP/Downloads/961616942-1-PB.pdf 